\title{
Variability of cutting regimes in small private woodlots of south-western France
}

\author{
Gaëtan Du Bus DE WARnAfFe, Marc DeconchaT*, Sylvie LAdET, Gérard BALENT
}

UMR 1201 Dynafor INRA/INPT-ENSAT, Chemin de Borde Rouge, BP 52627, 31326 Castanet-Tolosan, France

(Received 19 September 2005; accepted 14 June 2006)

\begin{abstract}
The small scale forest holdings are very common in Europe, but their management is not well known. The classical principes of forest management and of silviculture being rarely applied, their management is often seen as purely opportunistic, and even chaotic. To overcome this first sight, a detailed analysis of management practices in six private woodlots from two municipalities in south western France was done, with semi-directive interviews of the owners and an dynamic analysis of a chronological series of aerial pictures. The "said" practices (from the interviews) and the "seen" practices (from the aerial pictures) were crossed in a GIS and allowed to build the chronology of logging operations in any points of the woodlots from 1938 to 2003. The data from interviews and from aerial pictures fit together provided useful complementary information. They showed that there were no permanent spatial management unit, the logged areas being defined according to the local and current conditions. The silvicultural strategies and their dynamic have been described. The spatial-temporal complexity of the social and technical factors of the logging decision was acknowledged as a key explanation of the discrepancy between these small scale silvicultural systems and the classical systems.
\end{abstract}

coppice / fragmented forest / forestry practices / logging dynamic

Résumé - Variabilité des régimes de coupes dans des taillis de petites forêts fragmentées du sud-ouest de la France. La petite propriété forestière est très commune en Europe, mais sa gestion est mal connue. Les grands principes d'aménagement et de sylviculture la pénétrant très peu, sa gestion est souvent perçue comme purement opportuniste voire chaotique. Pour dépasser cette première approche nous procédons à une analyses fine des pratiques de gestion dans six petits bois privés de deux communes du sud-ouest de la France, au moyen d'entretiens semi-directifs avec les propriétaires et d'analyses d'une série de photos aériennes. Une méthode d'interprétation dynamique des photos aériennes est mise en œuvre. Les pratiques «dites », les pratiques «observées » et leur croisement dans un SIG permettent de décrire la suite des coupes réalisées en chaque point des six bois de 1938 à 2003. Les données issues des entretiens et des photos se contredisent rarement et se complètent utilement. Nous montrons qu'il n'existe pas d'unités de gestion permanentes, les unités de coupe étant définies de manière conjoncturelle. Nous décrivons les stratégies sylvicoles au moyen de plusieurs indicateurs et montrons leur évolution. L'étude met l'accent sur la complexité de l'organisation spatio-temporelle des coupes et des facteurs techniques et sociaux permettant de l'expliquer, et analyse la cohérence de stratégies sylvicoles en rupture avec les évolutions de la filière-bois internationale.

taillis / forêt fragmentée / pratiques forestières / dynamique des coupes

\section{INTRODUCTION}

Besides the large privately or publicly owned forest estates, there are in the world and particularly in Europe highly fragmented privately-owned forests. For example, twelve million private owners possess sixty five percent of the European Union's forests and on average own 4.9 ha of woodlots [42]. In France, 96\% of forest owners own less than 10 ha of woodlots [42]. This small private forest is broadly distributed throughout the country and structures the rural landscapes; it therefore plays a major ecological role, notably with respect to biodiversity and water flows [1] and, consequently, requires particular attention in rural planning policies. Ecologically efficient regional planning must simultaneously take into account the ecological and landscaping functions of forests and the variety of objectives of the owners concerned [9,26,36,37].

However, the methods applied to manage these small private forests - small-scale forestry, have not been studied in

\footnotetext{
*Corresponding author: marc.deconchat@ toulouse.inra.fr
}

any great detail whereas certain studies have highlighted the great differences in forestry practices according to the type of owner $[13,31,41]$. The notions developed by large-scale forestry - the foundation of modern forestry - such as the division into management units, inventories, planning documents, etc., do not apply for small-sized woodlots which are, as a general rule, free from regulatory obligations [17]. Only some North American $[4,15,25]$ and Scandinavian $[23,29,32]$ studies have examined the management of small-sized properties (20-30 ha) with respect to the average surface areas in those regions, but which are nevertheless large in comparison with what is found on southern Europe. Due to a lack of information, and also in the face of the apparent complexity of the practices of owners of small private forests, management is often quickly qualified as opportunistic [8] and does not seem to satisfy any particular logic $[18,20,24,28]$. The most common silvicultural system in France is based on coppice associated to stand tree retained to produce timber wood. The silvicultural operation are often reduced only to clear cut logging of 


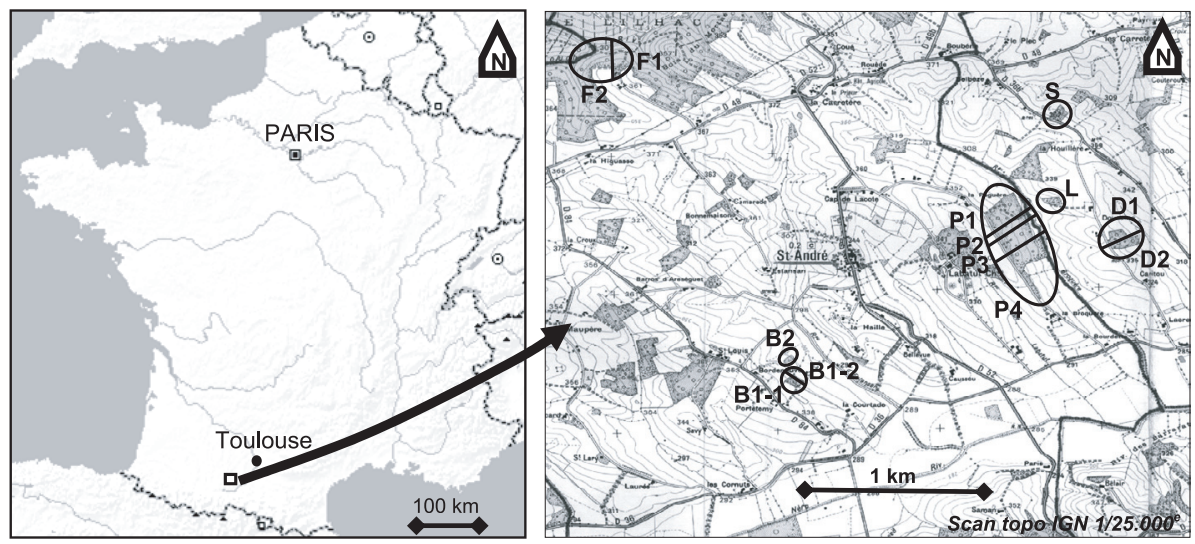

Figure 1. Location of the studied woodlots. The letters identify the woodlots and the numbers indicate the entities owned by different people (land-register plots).

coppice and a part of the standard trees on small section [10]. However, it is likely to have a large variability into this general model that was probably more uniform by the past than now [40].

Besides, it is not very likely that rural society would leave a natural resource as important as this to evolve without having set goals and developed means for controlling their accomplishment. We assume that the management exercised by forest smallholders satisfies a range of different logics that can be grasped through a detailed description of the practices, without any presumptions being made concerning the time and spacerelated organisation of these practices.

Our team studied in detail the management practices in a limited number of small privately-owned woodlots in southwest France. This retrospective analysis covering the period from 1938 to 2003 has allowed us (1) to seek for spatial management units, whether temporary or permanent, and (2) to characterise and explain the diversity of the owners' forestry strategies and their variability in space and time. The results may help to model these forest dynamics with a better accuracy, provide input data for ecological studies and contribute to a better forest management.

\section{METHODOLOGY}

\subsection{Region and woodlots studied}

The study focussed on two rural districts on the "Coteaux de Gascogne", in south-west France (Fig. 1). The region is characterised by a temperate climate with oceanic influences accompanied by a slight Mediterranean influence. Its relief shows an alternation of valleys and hillsides, with an altitude varying between 280 and 370 metres. The region is not very densely populated, and is still largely agricultural. The farms are for the most part dedicated to cattle-rearing mixed farming (hillsides) or large-scale crops (valleys) and, on average, include 4 ha of woodlots [44]. The total wooded surface area represents 7 and $26 \%$ of the two districts, but is made up of a multitude of small copses and of a part with large forest tracks. Most of the woodlots have a two-storey oak-hornbeam grove appearance [7], a coppice with standing trees growing from seed $\left(\mathrm{ca} .30 \cdot \mathrm{ha}^{-1}\right)$ [22]. Coppice is usually assumed to be logged each 30 years by clear cutting of small sections with farm machines to produce fire wood mostly. A part of the standard trees can be cut as well, to be sold or used as timber wood [10].

Earlier works in France have examined woodlots belonging to a certain number of farmers chosen at random over a relatively large area [35]. But such an approach does not make it possible to study the internal heterogeneity of the woodlots and its links with the management practices because very often an isolated woodlot belongs to more than one owner. We have preferred to choose several woodlots that are close to each other and to study them entirely and in depth. This choice makes it easier to analyse the heterogeneity of the ecological structure and of the factors defining them, and also to study the social determinants of the practices through an ethnographical study [40]. The sample consisted of 12 land register plots from six isolated woodlots of increasing surface areas (0.7-11.2 ha, total area $=22$ ha), including a part of a large forest; area is considered as one of the main factor influencing forest management and ecological processes in the study area [40] (Fig. 1). These woodlots have been studied during the same period for their ecological characteristics and belong to a long term study site for ecological and sociological interactions about forest [11]. They are located in similar ecological conditions; the dominant species are: pubescent (Quercus pubescens) and pedunculate $(Q$. robur) oak, hornbeam (Carpinus betulus), wild cherry (Prunus avium) and wild service tree (Sorbus torminalis).

\subsection{Data acquisition and analysis}

The method was based on two independent approaches: (1) semidirective interviews to determine the practices "as told" by the people concerned and (2) analysis of aerial photographs to identify the practices "observed" through their effects on the forest structures, that is to say essentially the cutting operations. These two approaches are considered, a priori, to be complementary since the interviews provide information on practices which may no longer be visible and the analysis of the aerial photographs verifies the stated practices through their consequences (Fig. 2). We preferred to carry out the interviews before analysing the aerial photographs so that we could approach the owners without any prior knowledge of their practices. All the data - whether provided by the interviews or by analysis of the aerial 
Table I. Logic used for determining possible cutting dates, based on the landcover classes of polygons on successive aerial mission photographs (5 years or more between two aerial missions). Code for land cover class: cutting without standards (C), cutting with standards (CR), young coppice without standards (R), young coppice with standards (RR), adult stand (P).

\begin{tabular}{lll}
\hline Class in mission $n$ & Class in mission $(n-1)$ & Possible cutting dates \\
\hline $\mathrm{C}, \mathrm{CR}$ & $\mathrm{C}, \mathrm{CR}$ & Mistake, verify photo-interpretation \\
& Others & Date of photo $n-(0$ to 4 years $)$ \\
$\mathrm{R}, \mathrm{RR}$ & $\mathrm{C}, \mathrm{CR}$ & Date of photo $n-(4$ to Intermission +4 years $)$ \\
$\mathrm{P}$ & Others & Photo $-(4$ to 16 years $)$ \\
\hline
\end{tabular}

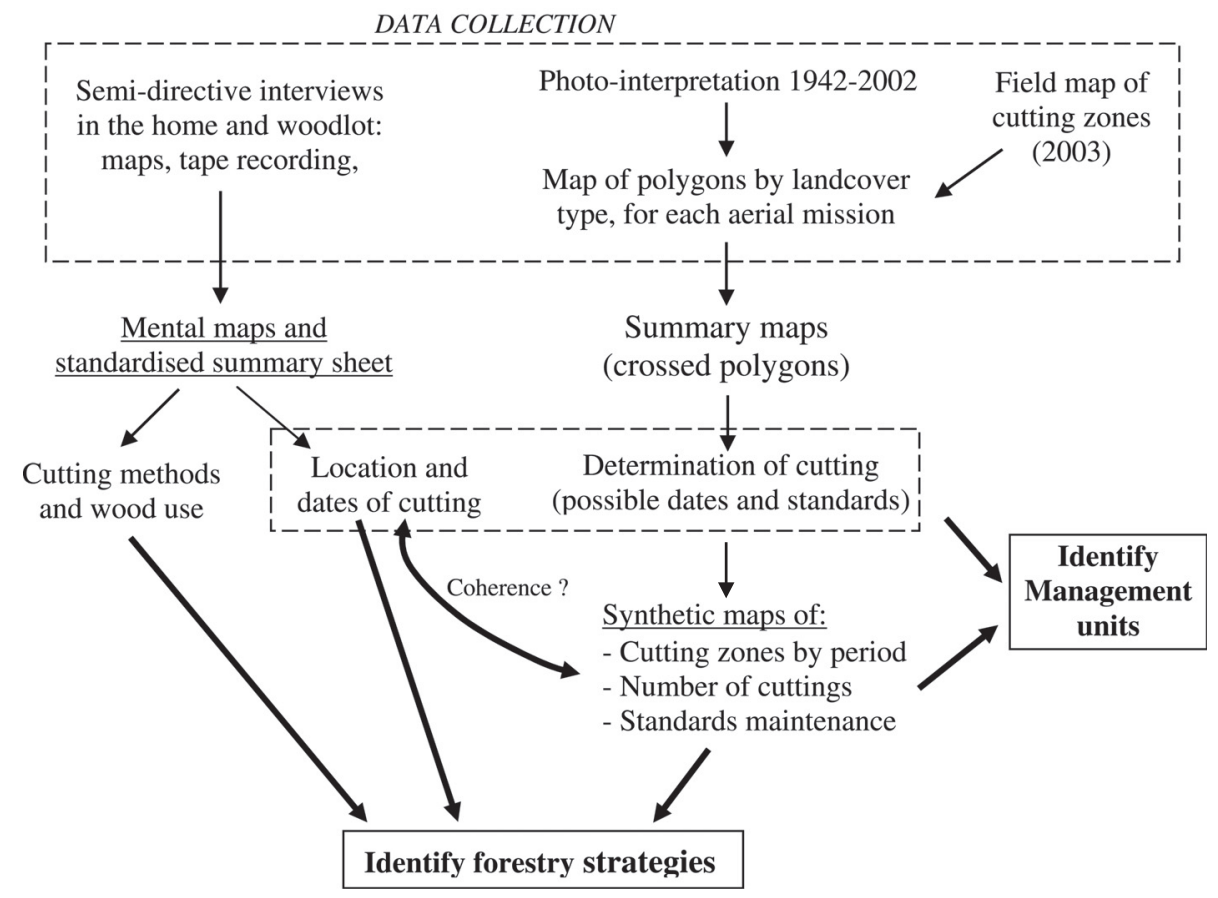

Figure 2. General data collection and analysis process. See text for detailed explanations on the method.

photographs - were coded to construct a Geographical Information System (GIS) under Arc-View ${ }^{\circledR}$ (ESRI).

Two two-hour semi-directive interviews were held with each owner: one at his home and the other in his woodlot. At his home, we explained the goal of the study and asked for information of a general nature (profession, age, land register plots owned); then we asked him to draw the areas that had been cut since 1938 on a map showing the empty shape of the woodlot and to detail the cutting procedures (people involved, season and equipment used, standards maintained); finally we asked him what use was made of the wood that was cut (home-consumption, sold, etc.) since 1938. In his land register plots, we completed the information obtained; seeing the trees and the logging signs generally helped the owner remind, explain his practices and modify the previous map drawn on table. The survey in the woodlot was organized in order to cover the largest part of the ownership (according to the land register) but this was constrained by the reduced mobility of some old owners and the dense vegetation of some parts of the woodlots. The paths and the edges were the generally used to explore the woodlots and were usually described as important features to organize logging operations. We thus obtained, for each plot defined by one woodlot and one owner, a "mental map" of the cutting regime [38] and a summary sheet. The mental maps were carried over to the GIS with the joint construction of a cross-reference table indicating the cutting dates and the people involved. This made it possible to reproduce, more or less precisely depending on the case, the cutting sequence from 1938 to 2003.

As for the analysis of the aerial photographs, we used eight missions conducted by the IGN (French National Geographical Institute) with scales comprised between $1 / 20000$ and 1/31 250 (1942, 1953, 1962, 1971, 1977, 1984, 1992, 2002) and one mission by the IFN (French National Forest Inventory) at the scale of 1/17 000 (1996). We chose to interpret the aerial photographs starting with the first mission (1938) so as to gain a progressive vision of the changing landcover, which is equivalent to a progressive photointerpretation [34]. The principle consists of modifying the shape of a copy of the polygons of a given year $n$ to represent the state of year $n+d, d$ being the time between two photography missions. This method ensures that the boundaries that are not changed between the two dates effectively correspond to each other, thus avoiding deviations caused by any slight geo-referencing differences. The photographs were analysed using optical stereoscopy; the discontinuities were carried over to the screen using the mouse, on a recently taken 
aerial photograph background scanned with a resolution of 800 dots per inch (dpi). For each mission, we circumscribed polygons defined by their land cover class, according to the following typology: cutting without standards $(\mathrm{C})$, cutting with standards $(\mathrm{CR})$, young coppice without standards $(\mathrm{R})$, young coppice with standards (RR), adult stand $(\mathrm{P})$, agricultural area $(\mathrm{A})$ and fallow land $(\mathrm{F})$ - provided that they were wooded at the time of one mission at least. Indeed, high forest is very rare in these private forests [7]. The photographs of the 1971 and 2002 missions were of mediocre quality not only because of the scale used $(1 / 30000$ and $1 / 31250)$ but also due to the deformations along the sides of the picture. For 1971, the information was processed with great care and for 2002 it was completed by a map of the current stands (2003) observed in the forests on the basis of transects $30 \mathrm{~m}$ apart, and using the same land cover classes. This map of the stands made it possible to validate the class determination criteria based on the land cover shown by aerial photography.

So as to be able to use the C, CR, R and RR classes as indicators of the cutting dates, coppice limit heights were established by relating the types obtained by stereoscopy with field observations. The limits between $\mathrm{C}$ or $\mathrm{CR}$ and $\mathrm{R}$ or RR were fixed at a height of $1 \mathrm{~m}$, which is equivalent to 4 year's growth; the limit between $\mathrm{R}$ or RR and $\mathrm{P}$ was set at $6 \mathrm{~m}$, that is to say 16 year's growth.

The maps obtained for the various missions were crossed using GIS's geo-processing functions so as to obtain a map summarising the years 1942 to 2003 made up of all the basic polygons resulting from the intersection of the polygons on each mission's map. Each polygon on the summary map is therefore characterised by a succession of states forming a forestry itinerary, where two neighbouring polygons have a different itinerary or belong to different owners. For example, a polygon on the summary map could have the following itinerary: $1942 \mathrm{P} \rightarrow 1953 \mathrm{CR} \rightarrow 1962 \mathrm{RR} \rightarrow 1971 \mathrm{P}$, etc. which means that the portion of space concerned by the polygon was an adult stand in 1942, was cut with standards in 1953, was a young coppice with standards in 1962 and has been an adult stand in 1971. We can therefore deduce cutting took place sometime between 1949 and 1953.

An initial analysis of these data consists of establishing a possible cutting date bracket for each basic polygon by establishing the relationship between the types of land cover for consecutive missions. To do this, we used the logic diagram shown in Table I which identifies the possible successions and makes it possible to assign a date to the cuttings that have been identified, considering that it takes 4 years for a cutting operation to be no longer directly discernable on the aerial photographs. This makes it possible to know the cutting sequence applied to each polygon between 1938 (1942 minus 4 years) and 2003. In order to represent the cutting dynamics we have chosen a breakdown of the six decades into 3 periods, represented by three maps: war and reconstruction period (1938-1959), boom period (1960-1981), contemporary period (1982-2003). The process also makes it possible to spatialize the total number of cuts between 1938 and 2003 and the standards maintenance index, defined as the number of cutting operations with standards related to the total number of cutting operations. The size of the annual cutting units cannot be determined precisely since the cuts carried at 4-year intervals become confused as classes $\mathrm{C}$ and $\mathrm{CR}$ on the aerial photographs.

Interview - aerial photographs summary

By superposing the geo-referenced maps in the same cartographic system (GIS), we could compare the dates and places of cutting indicated by the interviews and those indicated by the aerial photographs (Fig. 2). When the information from the mental maps was not contradicted by the information from the aerial photographs, we assumed the mental map information to be pertinent; we then completed the summary maps of the aerial photographs with any cutting operations that may have been indicated by the mental maps but not by the aerial photographs.

The assessment maps obtained then allowed us to determine whether stable management units were established over time, and to describe each owner's forestry strategies (Fig. 2). We drew up a summary table making it possible to visualise the practices and how they have changed from 1938 to 2003 using the following indicators: the extent of the cutting operations, their periodicity (rotation), their spatial arrangement, the maintenance of standards, the main features of cutting (people, season, equipment) and the main use made of the wood that has been cut. We use a scale of four levels for the extent of cutting, rotation and maintenance of standards: $0=$ null or very low, $1=$ low, 2 = medium, 3 = high. As for the spatial arrangement of cutting, there were three possible classes: $\mathrm{A}=$ adjacent cuttings, $\mathrm{S}=$ scattered cuttings, $\mathrm{B}=$ border cuttings. Concerning the people involved we used four classes: $\mathrm{O}=$ owner alone, $\mathrm{T}=$ owner and son together, $\mathrm{S}=$ son or other relative of the owner, $\mathrm{A}=$ other. The use made of the wood was divided into three classes: $\mathrm{F}$ = firewood only, $\mathrm{B}=$ firewood and construction, $\mathrm{S}=$ firewood and sale of timber or firewood. Lastly, for the season and equipment, the interviews did not justify the use of any classification of the responses (Tab. III).

\section{RESULTS}

\subsection{Interviews ("as told" practices)}

\subsubsection{Management units and location of the cuttings}

A mental map was obtained for each woodlot (Fig. 3), but with a highly variable degree of precision. The information gathered was very precise for three woodlots (P-1, P-3, F-1), averagely precise for six others (P-4, D-2, B1-1, B1-2, B2, F-2) and not precise for the remainders (D-1, L, S, P-2), giving in terms of surface area the proportions of 39,43 and $18 \%$ respectively. Since the respondents were aged between 32 and 80 , going back to 1938 represented a significant effort for the older ones and was obviously impossible for the younger ones except in the case of an oral transmission of their practices by the father. The latter remembered quite precisely the dates and places of cutting going back to between 1985 and 1990 according to the case; between 1960 and 1985-1990 it was often possible to situate the cutting zones on the map, but the dates were approximate; between 1938 and 1960, memories were hazy or nothing can be remembered at all. It was therefore possible to trace the cutting sequence quite precisely for the period 1985-2003, but with a highly variable degree of precision for the period 1938-1985. Even in the case of very precise information (P-1, Fig. 3) the memory only rarely made it possible to date two consecutive cuts at a given spot in the woodlot, and therefore to characterise the cutting dynamics over more than one complete rotation.

However the mental maps and visits of the woodlots with the owners already suggested that the cutting units were not permanent since they were never materialised on the land by boundary markers or stones, nor were they planned in the long term. Some owners planned them in advance but only over 


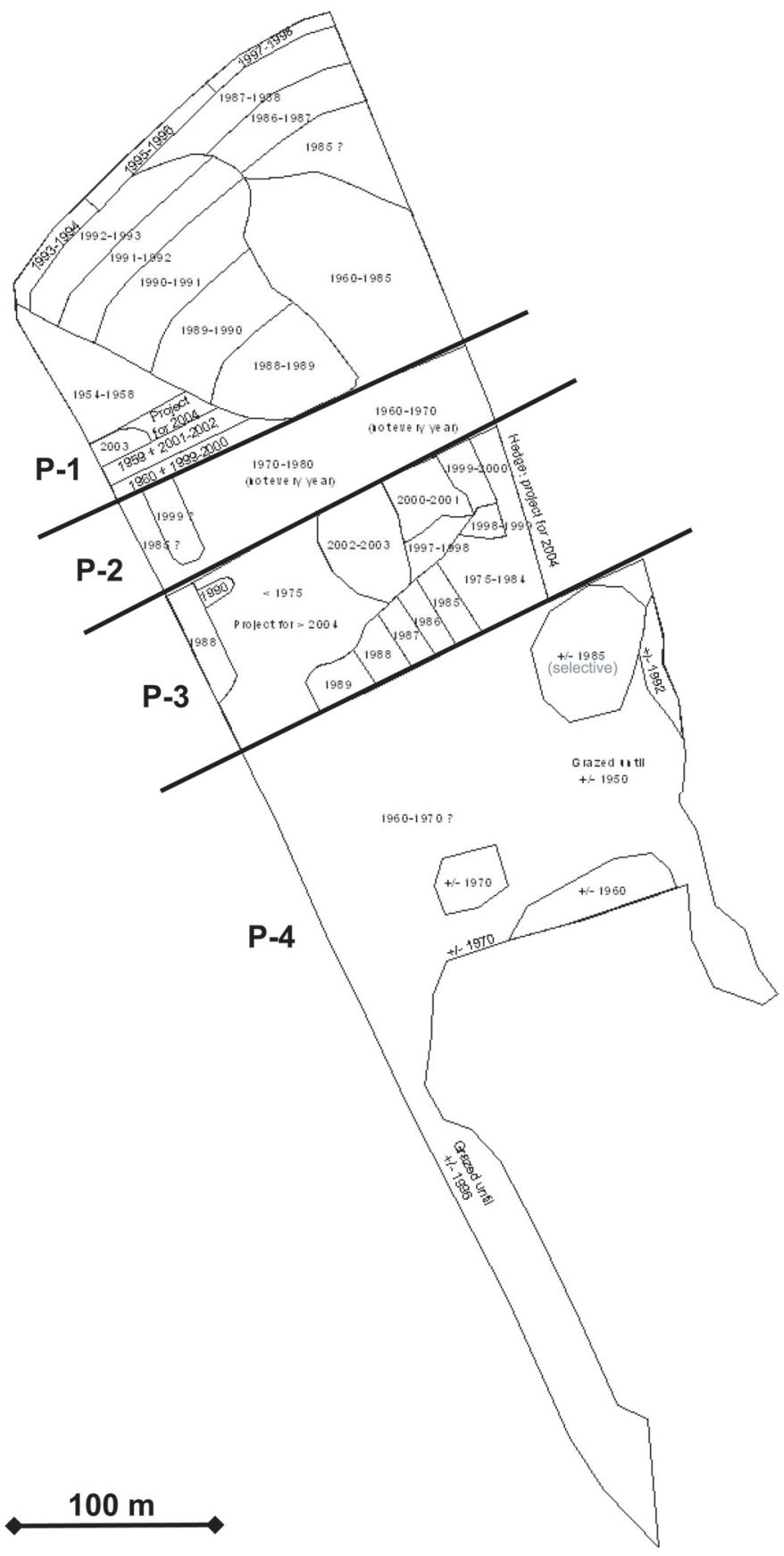

Figure 3. Mental map of the cutting zones for woodlot $\mathrm{P}$, reproduced on GIS. Bold lines indicate the property limits.

a few years. "I will cut again when my stack of logs starts to get low", said one owner. Some owners cut every year or every two years, others only when they needed the wood. The coppice rotation time was 25-30 years approximately in the forties and has increased to 35-40 years up to now, subsequent to a decrease in the growth of shoots due, according to the respondents, due to drought and/or browsing by deer.
Cutting was generally carried out where the coppices had trees with the greatest diameters, often next to the previous cutting; they therefore usually formed a continuous sequence, generally going from the bottom upwards when there is a slope (Fig. 3, woodlot P-1). They rarely exceeded 0.5 ha. They were delimited by the volume that the person had decided to cut and therefore according to the situation encountered (density, standards to be maintained, dead and rotting trees) and also according to the household's needs, as shown by the decrease in the amount of cutting after 1993 at P-1 (Fig. 3), corresponding to the installation of a wood stove requiring less wood.

As for the edges, they were cut more frequently and over a constant width. They can therefore be considered to be working zones with stable boundaries, likewise for the tracks which are maintained every two or three years. The edges were considered to grow twice as fast as the interior of the woodlot. As a general rule they were "rectified" around crops, that is to say the trees or branches that protrude out of the wood were cut annually or every two or three years; on the edge of meadows cutting was more irregular and depends on the demands of the meadow's owner. This was done using an angle mower, a chainsaw from the tractor's fork (for branches) or simply by felling the trees on the edge. But the maintenance of the edge may represent a real cutting operation that meets the annual firewood requirements (Fig. 3, north edge of P-1).

The regeneration of the stands is always natural (shoot + seedling); no planting was identified in the woodlots studied. Clearing, thinning of seedlings, early thinning and pruning were never carried out. The owners consider that beyond a certain age of trees, it is necessary to intervene because "the trees eat each other", however thinning out is limited to sanitary operations to eliminate the dead trees and sometimes, near to the cutting, to isolate some valuable shoot from others. They considered that it might be worthwhile to select the saplings or shoots before the coppice cutting to favour the best subjects, but none of them does it. Their attitude was nonetheless coherent, since the risks of depreciation of the stand resulting from this absence of thinning were known and accepted.

The dominant type of forestry was therefore that of coppice with standards, with small-scale cutting operations and minimal intervention. None of the owners had any contacts with the forestry office technicians, their link with the profession being limited to occasional meetings with the village sawmill. Relations between neighbours seemed to be the key factors in the choice of their forestry actions. However it could be noted that in the population studied, one owner was intuitively close to an forestry of irregular tall stands (F-1): he did not delimit cutting zones but decided with a buyer which trees were to be felled (high quality timber); after felling, he cut the crown for his firewood reserve, and took the opportunity to do some selective felling in the surroundings. Clear differences of views appeared with the neighbouring owner who had coppices with standards and defended this peasant tradition. Such differences between neighbours were frequent, particularly concerning the density of the maintained standards, but were often in the framework of a cordial relationship. 


\subsubsection{Cutting techniques}

Cutting was always carried out from January to March since, according to the respondents, the sap is low and the days are longer than in November-December, and cutting was usually carried out during dry weather and at the time of a low moon - at least when the decision to cut was taken by an elderly owner. Hedges, however, were often cut again in the spring to limit regrowth. The owners generally spend between one and two weeks a year cutting in their woodlot. The trees were cut with an axe and trimmed with a "croissant" (long-handled sickle) until 1960-1970 as the case may be, but the sickle was still often taken to the cutting site for small jobs, in particular to remove bushy and prickly vegetation. The length of the logs cut was variable $(0.5 \mathrm{~m}, 1 \mathrm{~m}$ or $2 \mathrm{~m}$ ). These logs were stacked manually and were generally removed from the woodlot at the end of the next summer. The people involved cut and stack between 5 and $10 \mathrm{~m}^{3}$ a day. The firewood was often split with a collective tool belonging to a CUMA (Farm Machinery Utilisation Cooperative), generally outside the woodlot, after skidding. The logs were transported by oxen until 1960-1970 as the case may be, the first tractors (nineteen fifties) only being used in the fields. The tractor's hopper is now loaded either by hand or using the CUMA's winch for the large logs. When the logs were small, the tractor was left on the edge of the woodlot to avoid damaging its structure and the tyres. However the tractor's fork is often used for chainsawing at a height and for carrying logs.

\subsubsection{Standards maintenance}

According to all the owners, when cutting, trees must be left approximately every 15-20 m - which corresponds to a density of 25 to 45 trees/ha. These standards were preferably chosen from among the free-standing oaks and were called baliveaux (sapling), quarantins (forty-year old trees) or gros chênes (large oaks) according to their diameter. Wild cherries were also appreciated, and ash and sweet chestnut were also sometimes kept; in no event were hornbeams considered to be worth keeping. The diameter of Wild Service trees (Sorbus torminalis) were usually too small to attract the attention of the person doing the cutting. A gap was created wherever there was no wood considered to be worth keeping.

\subsubsection{Use made of the wood}

Only a few decades ago a large range of forestry products were used, including the thorns taken from the undergrowth which were used to heat bakers' ovens; and this clearing left the undergrowth accessible to animals in dry periods. Nowadays, cutting is usually carried out to obtain firewood, as well as to "straighten up" the edges and "clean up" the woodlots (dead, rotting, lightning-struck trees). Most owners have oilpowered central heating, but this is only a recent development; so they only burn wood in one or two fireplaces. Affouage cutting (right to cut in the common woodlots) was used intensively when everyone exclusively heated their homes with firewood. Firewood was only taken from private woodlots when the affouage cutting and "border" produce (edges of woodlots, hedges, riverbanks) was not sufficient. Some households still benefit from affouage rights, and some still make faggots, while the others light their fires using fruit crates and newspapers.

Timber cutting for home consumption (house, stables, barns) was frequent up until the nineteen eighties but is rare today. Two owners still sell firewood and one sells timber on a regular basis, but the sale of timber remains rare. Standards are nevertheless maintained at the time of each cutting for a possible sale in the future and for landscaping reasons according to the people surveyed. The sale of industrial wood was very rare despite the fact that there is a large papermill nearby. The bartering of produce (e.g. wood for bread, faggots for bricks) has completely disappeared although, apparently, it was very common in the past. The utilisation of Robinia and chestnut as fenceposts is limited since the appearance of steel posts.

\subsection{Aerial photographs ("observed" practices) and coherence with the interviews}

\subsubsection{Extent of cutting}

The occupation class maps at the time of the various missions (Fig. 4) highlight the complexity of the dynamic interpretation. The areas cut were often small, of irregular shapes and were rarely superposed from one period to another. The trajectories of the basic polygons were highly diversified and sometimes complex.

Areas of the order of 2 ha may be exploited in one decade (Fig. 5), sometimes representing more than $50 \%$ of the surface area of a land-register plot. For the owners who cut every year (see Sect. 3.1), the extent of the unbroken areas exploited in each decade make it possible to evaluate the size of the annual cutting areas. The area cut in each decade tended to decrease over time in five woodlots (P-2, P-4, B1-1, D-1, D-2), to increase in four woodlots $(\mathrm{S}, \mathrm{F}-1, \mathrm{~F}-2)$ and to increase and then fall back in two others (B1-2, L); in the last two woodlots (P-1 and $\mathrm{P}-3)$, the evaluated scope of cutting showed a variation without any clear trend (Tab. II). The trend of decrease can be seen more clearly in Figure 6, where the six decades are grouped together in three equal periods.

\subsubsection{Cutting periodicity}

Certain areas have been cut two or three times, whereas others never seem to have been cut (Tab. II, illustration Fig. 7), but the interviews sometimes indicated that cutting had taken place in those areas (e.g. Fig. 7). The areas that had been cut twice in twenty years were exceptional and this concerns cutting on the edge of woodlots. The number of decades separating two cutting operations in the same place varied according 

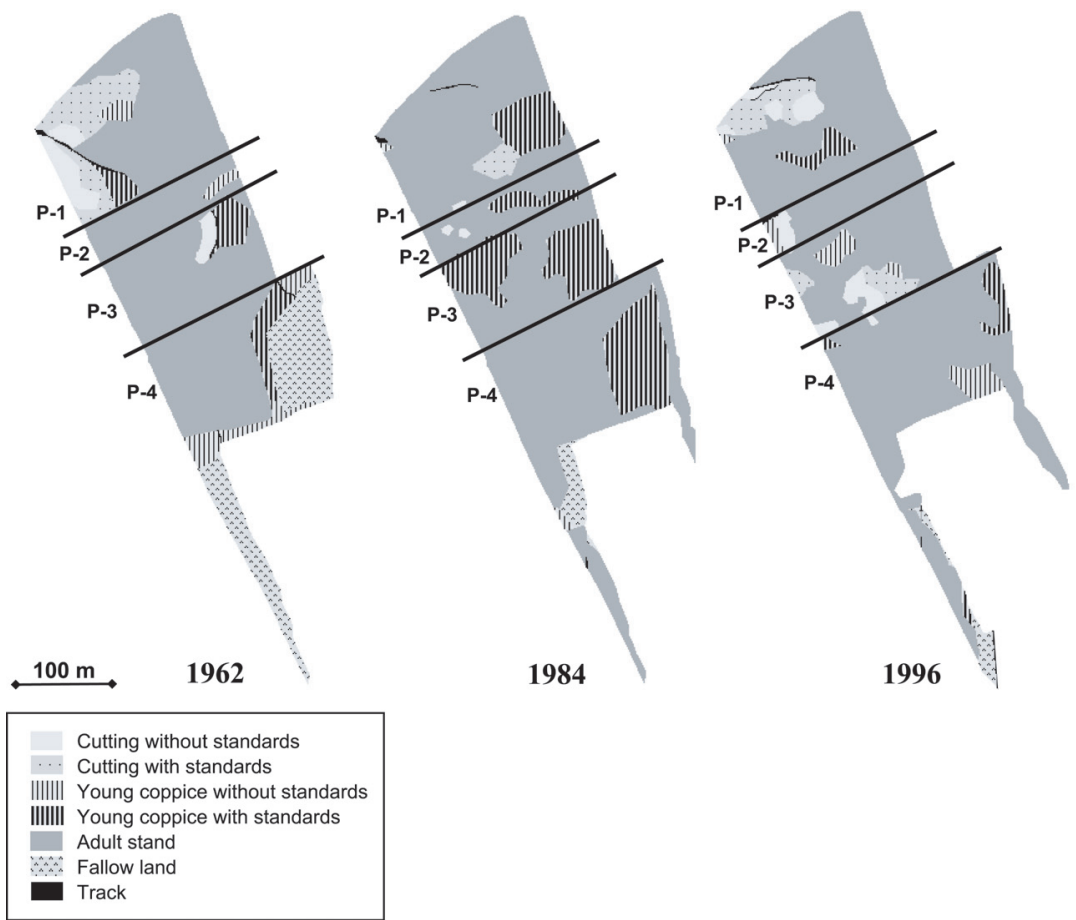

Figure 4. Example of digitized land cover maps (Woodlot P) obtained from three aerial photographic missions. Bold lines indicate the property limits.
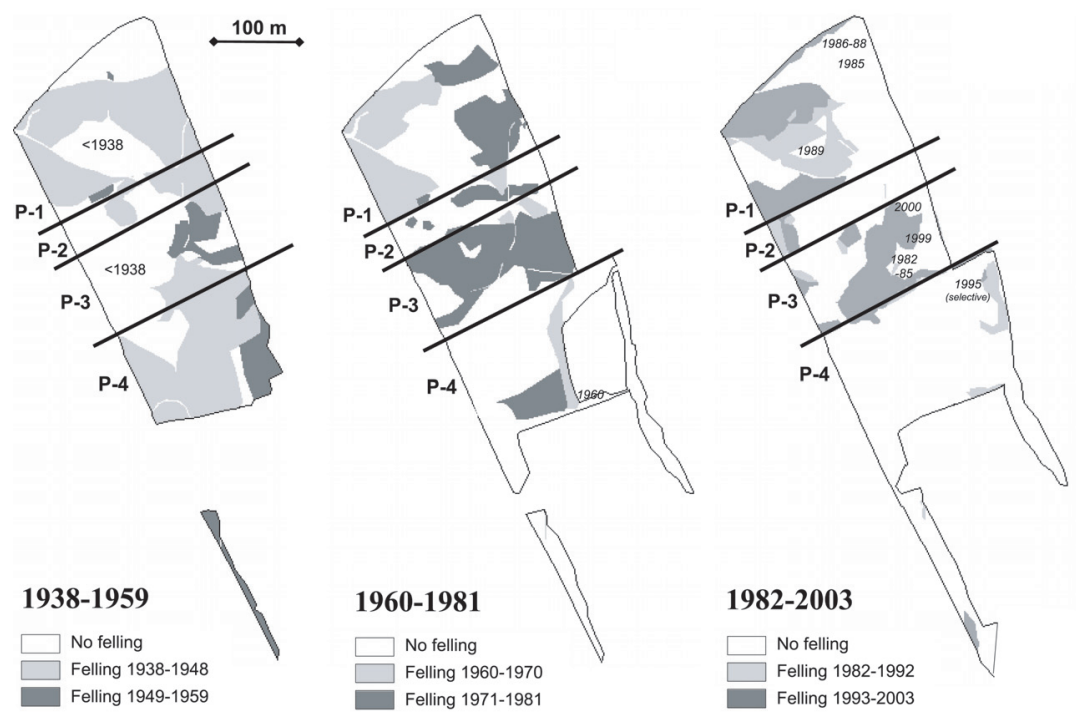

Figure 5. Estimated cutting dates from 1938 to 2003 for woodlot P, drawn from the analysis of nine sets of aerial photographs. The external limits of the forest are those given by the photograph taken at the date nearest to the end of each 20 year-period (1962, 1977 and 2002). Bold lines indicate the property limits. The dates in italics indicate the cutting operations mentioned by the owner (drawn in the mental map) but not visible on the aerial photograph. 
Table II. Percentage of the area of land register plot by number of cuttings, by period and by levels of standards maintenance, from 1938 to 2003 (6 woodlots, 12 owners).

\begin{tabular}{|c|c|c|c|c|c|c|c|c|c|c|c|c|c|}
\hline \multirow[t]{2}{*}{ Land register plot } & \multicolumn{4}{|c|}{ Number of cuttings } & \multicolumn{6}{|c|}{ Part of the area cut ${ }^{\mathrm{a}}$} & \multicolumn{3}{|c|}{ Cuttings with standards ${ }^{\mathrm{b}}$} \\
\hline & 0 & 1 & 2 & 3 & $\mathrm{p} 1$ & $\mathrm{p} 2$ & p3 & $\mathrm{p} 4$ & $\mathrm{p} 5$ & p6 & None & Part & All \\
\hline$\overline{\mathrm{P}-1}$ & 16 & 33 & 38 & 13 & 54 & 1 & 30 & 22 & 18 & 29 & 2 & 18 & 81 \\
\hline $\mathrm{P}-2$ & 30 & 49 & 19 & 2 & 41 & 0 & 6 & 22 & 6 & 8 & 38 & 18 & 44 \\
\hline P-3 & 10 & 44 & 31 & 15 & 18 & 16 & 4 & 65 & 3 & 40 & 3 & 24 & 72 \\
\hline P-4 & 44 & 42 & 14 & 0 & 57 & 21 & 10 & 13 & 5 & 4 & 32 & 3 & 65 \\
\hline B1-1 & 3 & 67 & 30 & 0 & 19 & 46 & 12 & 44 & 8 & 0 & 35 & 30 & 65 \\
\hline B1-2 & 72 & 25 & 3 & 0 & 5 & 0 & 10 & 11 & 7 & 0 & 59 & 5 & 36 \\
\hline $\mathrm{L}$ & 7 & 44 & 38 & 11 & 0 & 33 & 0 & 93 & 27 & 1 & 25 & 49 & 26 \\
\hline S & 50 & 44 & 6 & $<1$ & 0 & 6 & 0 & 9 & 40 & 5 & 38 & 10 & 52 \\
\hline F-1 & 31 & 44 & 17 & 8 & 0 & 11 & 33 & 12 & 21 & 15 & 20 & 9 & 71 \\
\hline F-2 & 15 & 43 & 40 & 2 & 5 & 34 & 9 & 28 & 25 & 28 & 16 & 26 & 58 \\
\hline D-1 & 25 & 54 & 20 & $<1$ & 33 & 26 & 14 & 1 & 19 & 3 & 40 & 11 & 49 \\
\hline D-2 & 34 & 31 & 32 & 3 & 12 & 32 & 14 & 20 & 4 & 16 & 34 & 34 & 33 \\
\hline
\end{tabular}

a p1: 1938-48; p2: 1949-59; p3: 1960-70; p4: 1971-81; p5: 1982-92; p6: 1993-2003.

b None: $\%$ of the area of the parcel where none of the cuttings were carried out with standards; part: $\%$ of the area of the parcel where standards were kept for 1 or 2 cuttings if 3 cuttings were performed, and for 1 cutting if 2 cuttings were performed; all: \% of the surface of the parcel where all the cuttings were performed with standards.

Table III. Synthetic view of the forestry strategies applied in the 12 land-register plots, and of their evolution from 1938 to 2003 . The first code (before arrow) indicates the practices at the beginning of the period, the second code (after arrow) gives the practice at its end (last decades).

\begin{tabular}{|c|c|c|c|c|c|c|c|c|c|c|c|c|c|}
\hline Criteria & Indicator & $\mathrm{P}-1$ & P-2 & P-3 & P-4 & D-1 & D-2 & $\mathrm{L}^{\mathrm{a}}$ & $\mathrm{S}^{\mathrm{a}}$ & B1-1 & B1-2 & F-1 & F-2 \\
\hline \multirow{4}{*}{ Cuttings ${ }^{\mathrm{b}}$} & Cutting size & $3 \rightarrow 3$ & $1 \rightarrow 0$ & $2 \rightarrow 2$ & $2 \rightarrow 0$ & $2 \rightarrow 1$ & $2 \rightarrow 1$ & $2 \rightarrow 1$ & $2 \rightarrow 2$ & $1 \rightarrow 0$ & $\rightarrow 0$ & $1 \rightarrow 1$ & $2 \rightarrow 2$ \\
\hline & Rotation $^{\mathrm{d}}$ & $1 \rightarrow 1$ & $2 \rightarrow$ & $1 \rightarrow 1$ & $2 \rightarrow$ & $2 \rightarrow 3$ & $2 \rightarrow 3$ & $1 \rightarrow 3$ & $3 \rightarrow 3$ & $1 \rightarrow$. & $\rightarrow 2$ & $2 \rightarrow 2$ & $1 \rightarrow 1$ \\
\hline & Spatial organisation & $\mathrm{A} \rightarrow \mathrm{A}$ & $\mathrm{A} \rightarrow$. & $\mathrm{A} \rightarrow \mathrm{A}$ & $\mathrm{S} \rightarrow$. & $\mathrm{A} \rightarrow \mathrm{S}$ & $\mathrm{A} \rightarrow \mathrm{S}$ & $\mathrm{A} \rightarrow \mathrm{S}$ & $\mathrm{A} \rightarrow \mathrm{S}$ & $\mathrm{A} \rightarrow$. & $\rightarrow \mathrm{S}$ & $\mathrm{S} \rightarrow \mathrm{S}$ & $\mathrm{A} \rightarrow \mathrm{A}$ \\
\hline & Standards & $3 \rightarrow 3$ & $2 \rightarrow$ & $3 \rightarrow 3$ & $2 \rightarrow$ & $3 \rightarrow 2$ & $3 \rightarrow 2$ & $3 \rightarrow 1$ & $3 \rightarrow 2$ & $2 \rightarrow$ & $\rightarrow 3$ & $3 \rightarrow 3$ & $3 \rightarrow 2$ \\
\hline \multirow{3}{*}{ Cutting methods ${ }^{c}$} & People & $\mathrm{T} \rightarrow \mathrm{T}$ & $\mathrm{O} \rightarrow$. & $\mathrm{T} \rightarrow \mathrm{O}$ & $\mathrm{A} \rightarrow$. & $\mathrm{T} \rightarrow \mathrm{S}$ & $\mathrm{T} \rightarrow \mathrm{S}$ & $\mathrm{T} \rightarrow \mathrm{S}$ & $\mathrm{T} \rightarrow \mathrm{S}$ & $\mathrm{O} \rightarrow$. & $\mathrm{O} \rightarrow \mathrm{A}$ & $\mathrm{O} \rightarrow \mathrm{O}$ & $\mathrm{T} \rightarrow \mathrm{T}$ \\
\hline & Season & \multicolumn{12}{|c|}{ All in winter $\rightarrow$ All in winter } \\
\hline & Material & \multicolumn{12}{|c|}{ All axe, sickle and ox $\rightarrow$ All chainsaw (+ sickle) and farm tractor } \\
\hline Wood use $^{\mathrm{c}}$ & - & $\mathrm{B} \rightarrow \mathrm{S}$ & $\mathrm{F} \rightarrow$ & $\mathrm{B} \rightarrow \mathrm{F}$ & $\mathrm{F} \rightarrow$ & $\mathrm{B} \rightarrow \mathrm{F}$ & $\mathrm{B} \rightarrow \mathrm{F}$ & $\mathrm{B} \rightarrow \mathrm{F}$ & $\mathrm{F} \rightarrow \mathrm{F}$ & $\mathrm{F} \rightarrow$ & $\mathrm{F} \rightarrow \mathrm{F}$ & $\mathrm{B} \rightarrow \mathrm{S}$ & $\mathrm{B} \rightarrow \mathrm{F}$ \\
\hline \multicolumn{14}{|c|}{$\begin{array}{l}{ }^{a} \mathrm{~L}, \mathrm{~S} \text { are two woodlots owned by the same person. } \\
\mathrm{b} \text { Summary of data from aerial photographs and interviews. } \\
\text { c Data from interviews. } \\
\text { d Rotation = number of years between two cuttings at the same place. } \\
\text { Codes: Cutting size, rotation, standards maintenance: } 0=\text { null or very low, } 1=1 \text { low, } 2=\text { medium, } 3=\text { high; spatial organisation of cuttings: A = adjacent } \\
\text { cuttings, } \mathrm{S}=\text { scattered cuttings, } \mathrm{B}=\text { border cuttings; people: } \mathrm{O}=\text { owner alone, } \mathrm{T}=\text { owner and son together, } \mathrm{S}=\text { owner's son or relative, } \mathrm{A}=\text { other } \\
\text { person; wood use: } \mathrm{F}=\text { firewood only, } \mathrm{B}=\text { firewood and construction, } \mathrm{S}=\text { firewood and sale of wood; a dot }(.) \text { indicates an absence of identified cutting } \\
\text { practices. }\end{array}$} \\
\hline
\end{tabular}

to the owner and the situation (Fig. 5). It was impossible to calculate the rotation in the uncut areas or in areas that have only been cut once between 1938 and 2003; but these areas are sometimes well represented, up to $32 \%$ for woodlot $\mathrm{P}$ for example. However, assuming that in most cases, the 1938-2003 period was bracketed by a cut in 1930 and another one 2010, it was be possible to give an average periodicity per woodlot. We obtained a figure ranging from 39 to 74 years depending on the woodlot, with certain plots only being slightly exploited (P-2, P-4, B1-2, S, D-2) and others significantly more so (P-1,
P-3, F-2). A lengthening of the rotation period could nevertheless be seen between 1938 and 2003, for example in woodlot $P$ (Fig. 5).

\subsubsection{Spatial arrangement of cutting}

For each decade, the dynamic cutting maps (Fig. 5) showed continual cutting areas which indicates an adjacent cutting area organisation - this information was confirmed at the time 


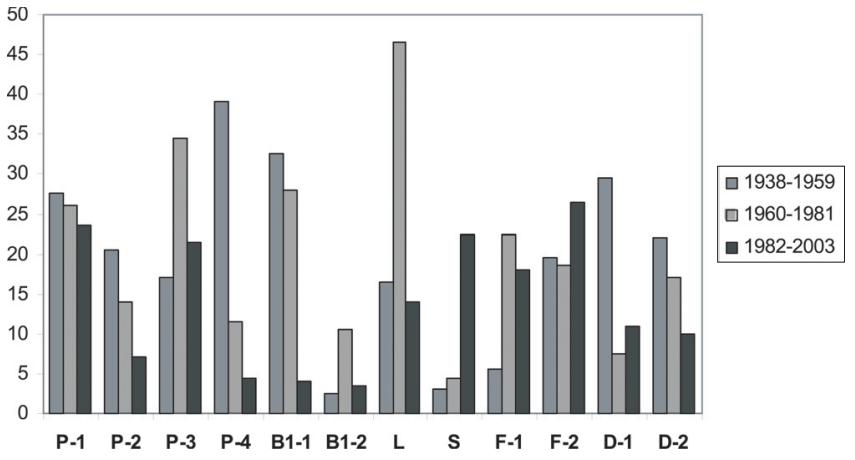

Figure 6. Proportion of the area cut in the 12 land-register plot (P-1 to D-2) during three periods: 1938-1959, 1960-1981 and 1982-2003.

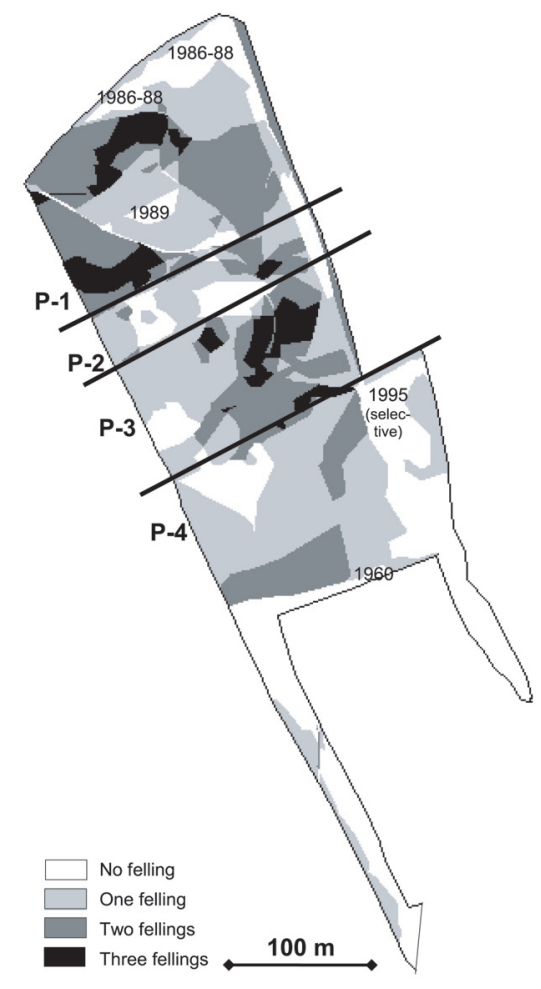

Figure 7. Number of cuttings applied in woodlot (P) from 1938 to 2003. Bold lines indicate the property limits. The dates indicate cutting operations mentioned by the owner, but not visible on any aerial photograph.

of the field visits and of the interviews. The cutting areas therefore generally represented a succession of areas in space over the years, which results in a continual gradient in the height of the stands which forces the successor to reproduce the same rotation scheme. However, over the last few decades, the cutting scheme has become significantly more randomised, with young farmers cutting when they have the time, where there are dead trees, or trees that have been broken or blown over by gales.

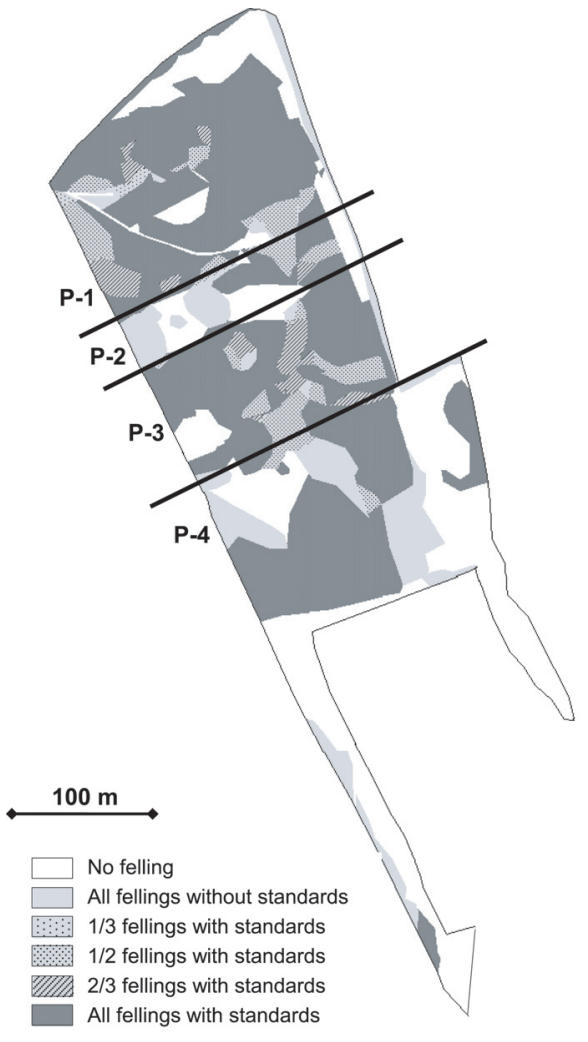

Figure 8. Part of the number of cuttings in which standards where maintained. Bold lines indicate the property limits.

\subsubsection{Standards maintenance}

Depending on the woodlot, standards have been maintained over 41 to $98 \%$ of the surface area submitted to cutting at least once (Tab. II). The maintenance of standards seems to be the general rule in certain woodlots (P-1, P-3, F-2) whereas it appears less frequent in others (B1-2, S, P-2) (Tab. II, Fig. 8). However B1-2 is a recently established woodlot; the cutting carried out there above all corresponds to a battle against the natural extension of the woodlot into the adjoining meadow.

\section{DISCUSSION}

\subsection{Summary: forestry strategies}

Earlier analyses [39] have made it possible to develop indicators given in the methodological section (Tab. III). The size of the cutting areas decreases or remains stable and the rotation increases in nearly all the woodlots. Generally speaking, the cutting areas represent a succession in space (adjacent cutting areas) but, in the majority of cases, the strategies are evolving towards a scattered cutting scheme. As for the people involved, it can be noted that, to begin with (1940-1950) the owner and his son worked together, but that this association was much rarer at the end of the period. There is, of course, a great and general change in the machinery used, but the cutting 
season has not changed. Lastly, the use made of the wood has changed significantly from a mixed utilisation to nearly exclusive use as firewood (usually to serve as an amenity rather than as the prime source of heating). An overview of the table shows that in a woodlot, the strategies may differ significantly from one owner to another (e.g. F-1 and F-2), as do the way that these strategies evolve (e.g. P-1 and P-2).

\subsection{Methodological questions}

\subsubsection{Interviews}

Access to the information was sometimes difficult: firstly due to the respondents' lack of time (busy period on the farm, family problems, etc.); and sometimes also due to the impression that this type of "theoretical" work is not of any particular use for them or, even, of no use at all for anyone. Then, the memory was lost with the "young" owners (their parents having died) and sometimes there was a lack of precision in the discourse (e.g. difficulty reading and amending a map). The field visits could then, to a certain extent at least, clarify the information. Lastly, the respondents were sometimes slightly reticent to express themselves on their domestic organisation, since the INRA is seen as an administrative organisation close to the tax authorities. Particular attention must be paid to the vocabulary used, since the technical terms are not always understood or, at least, are not taken in the sense given to them by the researcher. This risk of bias has been identified in other regions (e.g. [14]: "did the respondents really understand what was meant by timber harvesting?"). In any case, a great deal of respect and a good sense of communication are essential for this type of work. In order to understand the motivations of the owners it was necessary to move away from standardised surveys and to adopt a qualitative approach [5], by proceeding with semi-directive interviews in the home and with field visits [30] rather than by phone [31], mail or e-mail [15,23].

\subsubsection{Photo-interpretation}

Experience shows that when analysing aerial photographs, it can be difficult to make the distinction between "without standards" and "with standards" types since the standards are sometimes young trees that are only slightly differentiated from the coppice in an aerial photograph, and to make the distinction between "young coppices with standards", "cutting with standards" and "adult stand" types when the density of the standards was great; hence, sometimes there is a lack of accuracy on the dates and cutting areas and on the standard index. A high density of standards also makes it impossible to delimit on the aerial photographs the cutting operations notified at the time of the interviews. This pleads in favour of low-altitude aerial photographs, scanned at a fine scale. A second limit to the method lies in the fact that it is impossible to determine the exact date of the cutting operations and the limit between two neighbouring cutting operations carried out at an interval of less than four years; the interviews are vital for clarifying this information. Third problem: we note that the edges appear to be unstable without it always being possible to identify the source of this instability. These edge fluctuations are generally attributed to real variations in the stand's limits (e.g. [20]), but our analysis suggests it may also sometimes be due to interpretation or geo-referencing errors.

\subsubsection{Agreement between "as told" and "observed" practices?}

The areas of good agreement between the "as told" and "observed" practices were in the majority. We cannot therefore speak, as was the case in Pennsylvania [14], of a disparity between the practices "as told" and "done" by small forestry owners. Certain areas were marked by relative agreement (cutting dates and areas were close), which illustrates the problems in the resolution of the aerial photograph analysis or of the accuracy of the owners' memories. As for the areas of disagreement, a distinction must be made between three cases: (1) cutting operation reported at the time of the interview without being identified on the aerial photograph, generally due to an high density of the standards; (2) cutting operation detected by the aerial photograph but not reported at the time of the interview, due to an incomplete memory; (3) great difference in the cutting areas for a given date or cutting date very different for a given area. In the first two cases different items of information are simply added to each other. The third case was rare in our study; it can point out the difficulty of the informant to legend the "mental map", but we must always proceed logically in order to determine which of the two sources of information seems to fit the context best (other information in our possession). Since it is not possible to verify the memory of the owners, we should place greater faith in the aerial photographs.

\subsection{Management units?}

The results clearly show that the notion of permanent management unit does not exist whether in the field or in the mental maps of the owners which immediately shows that their practices are very different from those implemented in large privately or publicly owned forests. However the harvesting of wood is generally not dispersed; it is concentrated on temporary management units with relatively hazy shapes ("units of practices"), defined by the owners' needs for wood at the time of cutting, which therefore stops when the requirement has been met. The units of practices produce a far more complex space-time arrangement than in planned forests, where the units are clearly defined at least for the planning period (generally 25 years). This particularity has an important consequence for spatially explicit model of the forest dynamics and its management, because the lack of easily identifiable spatial units implies to adapt the usual transition matrix models often used for such purpose.

The result maps of the history of logging operation and intensity produced in this study can be the input data for detailed ecological studies in these forests since it is well known 
that disturbances, such as logging, are a key factor for many biodiversity related processes [10]. It is generally difficult to get such kind of historical map of disturbances in small fragmented forests [21] and the method proposed in this study could be helpful for other projects aiming to relate disturbance regime and biodiversity at a fine scale.

\subsection{Diversity and changes in the forestry strategies}

The forestry strategies must be linked not only to the age of the owner and to his geographical distance from the woodlot [32], but also to other complex socio-cultural factors [3]. Some owners seem to have a particular taste for the forest and its management (woodlots P-1, P-3, F-1), others only show scant interest (D-1, D-2, S, L). The evolution of owner's interest for the forest often makes it possible to explain the continuation or abandoning of woodlot exploitation (extent of cutting, rotation). However, certain changes in the pressure of exploitation are due to other social processes. Indeed, cutting may have been abandoned further to the departure of the successors to work in town (P-2) [32], the disappearance of the sharecropping system (P-4) or a conflict between father and son (B1-1). Furthermore, the owner's interest for the forest alone does not make it possible to interpret the differences in terms of the spatial arrangement of cutting operations, the density of standards and the people involved. For example, scattered cutting operations may be the sign of exploitation by a non-owner (P-4), of systematic exploitation being abandoned (D-1, D-2, L, S) or of a management style approaching the continuous-cover forestry system (F-1). In this last case the owner unconsciously follows foresters, who nowadays tend to reject coppice with standards regime, which they see as being primitive and inefficient $[18,28]$.

The importance of the social processes also emerges from the study of other indicators. The variation in the maintenance of standards, for example, cannot be linked to the variation in the domestic needs for construction timber. Indeed, in this case the index would fall everywhere over time (due to substitution of wood by metal), which is not the case (Tab. III, last line). The interviews suggest, rather, that the practice of standards is for a large part maintained due to social pressures, thanks to a collective representation of woodlot as a heritage to be respected and the fact of not leaving standards is viewed poorly by the neighbours; the standards thereby represent a family savings fund which could, potentially, be used by the owner's descendants. The importance of viewing woodlot as a family heritage has been demonstrated in other countries (e.g. USA: [15]). As for the changes in the people involved, they can only be explained by examining in detail the farmers' households and how they function [39]. The fact that the son is alone may simply be due to the death of the father, combined with the absence of a grandson (P-3). The son's participation in the forestry work may be one of the conditions for officially taking over the farm, this succession providing access to worthwhile subsidies (P-1). Lastly, someone from outside the family may be put in charge of the work when the owner is not of rural origin (B1-2). The complexity of the fac- tors involved requires the analysis of each case individually, which imposes an ethnological analysis that we are attempting to carry out through an interdisciplinary approach (see [40]). The exact reasons for the choices are sometimes difficult to determine insofar as, as observed by Lönnstedt [30], "a longterm perspective, including traditions and a local network, affects a NIPF (Non Industrial Private Forest) owner's choice”.

\subsection{Place of these strategies in the national forestry}

The owners of these small isolated woodlots seem to apply forestry strategies that are apparently remote from the schemes proposed over the last decades by the French forestry profession, which is partly responsible for the significant regression in coppice-based regimes in France [28], also in regression since decades in other European countries (e.g. UK: [16]). The weak interaction between smallholders and forestry consultants seems to be widespread in the region, whereas crop consultants and farming periodicals play an important role, including in the area of forestry [44]. The terminology used to describe the forest and the practices is more "intuitive" and popular [18] than scientific or technical. But the forestry systems of these forest smallholders have probably been strongly influenced by the practices in place in the neighbouring district's forests [12], where the inhabitants' rights to firewood were added to the production of timber. The possible commercial outlets, like the "improvement" proposals made by the foresters, do not seem to interest the owners very much. The financial valorisation of the woodlots is therefore relatively low. Bohlin and Roos [6] noted that in Sweden the main motivation of forest smallholders for extracting firewood was not the revenue they could generate, but the need they felt to "clean up" the woodlots. A minimalist intervention essentially determined by the notions of "cleanliness" and "beauty" was also observed with the forest smallholders in Michigan [15]. The low profits made from selling the wood in the woodlots concerned by this study suggest a comparable phenomenon. These findings could be helpful to elaborate regional production orientations, as required by the French forestry policy, better adapted to the actual forestry practices.

However, the study suggests that the forestry strategies, use made of the woodlots and the needs of the household are entirely coherent as was suggested by other authors [27, 43]. Although the interventions are not planned a long time in advance, unlike on large properties, management cannot be qualified as being "less sustainable". Indeed the site's native species are maintained and varied species of standards are in general left at the time of each cutting operation, which maintains a balance between asexual and sexual reproduction. Although the cutting operations are relatively severe, they cover a small area, are carried out several decades apart and use light machinery, so that the soil is only very slightly subject to erosion. The difference essentially lies in the integration of the forestry system in the national and international timber market which, in the case of these small private woodlots, is virtually non-existent. This may reduce the procurement possibilities for the timber industry and merchants, but does not pose any 
problem for the users themselves or for the social and ecological environment.

\section{CONCLUSION}

The approaches involving semi-directive interviews and the analysis of sequences of aerial photographs are complementary; one without the other would lead to very incomplete results, which would not make it possible to correctly describe the forestry strategies of these smallholders. Here we are in agreement with Marcin [33] who pleaded for the integration of social sciences in the research into the management of forested ecosystems. The systems described appear to be complex, not in terms of technical standards - as is the case in the large publicly-owned forests - but rather in terms of the space-time distribution of the practices and in terms of the socio-cultural players and factors defining the practices and their organisation. A localised in-depth observation is required in order to understand them. Through a crossed analysis of the technical and social observations it is possible to evidence the functional links that exist between ecological and social systems [2].

The study shows that in the management of the small forest holdings of the "Coteaux de Gascogne" area, there are no stable management units, nor is there any long-term planning of the cutting operations and other tasks. This type of forestry appears to be both "adaptive" and "conservative". Adaptive because the practices (e.g. date of cutting, volume extracted) are adapted to the time and place ("reactive management" according to Girard et al. [19]), and conservative because the fundamental principles of the system are upheld (native species, cuttings of limited size and maintenance of standards). As noted by Lönnstedt [30] for small-scale Swedish forestry: "the owners have to handle short-term realities inside a framework of long-term preservation". The "unplanned" nature of this management style therefore does not make it possible to pass any judgement on the sustainability of the systems, even if they do effectively appear to be profoundly out-of-step with recent developments in European forestry. The apparent inertia of these management systems risks leading to the woodlots being abandoned, but nevertheless has the merit of having preserved their composition and structure and has, in all likelihood, maintained their soil in good condition. They have at least, until now, satisfied the needs of their owners and of their social environment, even if they have failed to meet the growing requirements of an increasingly global and unpredictable timber market.

Acknowledgements: We would like to extend our warm thanks to the owners who accepted to receive us and who permit the researchers and technicians at INRA Toulouse to continue their work. We would also like to thank the European Commission for financing part of this research (Marie Curie Fellowship), and the PSDR and CCRRDT programmes, as well as Alain Cabanettes, Anne Sourdril, Laurent Burnel, Laurent Raison and Jérome Willm for their essential help.

\section{REFERENCES}

[1] Balent G., La forêt paysanne et l'aménagement de l'espace rural, Études sur les systèmes agraires et le développement 29 (1996) 7-14.

[2] Berkes F., Folke C., Linking social and ecological systems - management practices and social mechanisms for building resilience. Cambridge University Press, Cambridge (UK), 1998, 459 p.

[3] Blandin P., Arnould P., Devenir des îlots boisés dans les plaines de grandes cultures, Rapport final du programme interdisciplinaire "environnement, vie et sociétés - systèmes écologiques et actions de l'homme", CNRS, Paris (France), 1996, 55 p. + annexes.

[4] Bliss J.C., Evidence of ethicity - Management styles of forest owners in Wisconsin, Forest and Conservation History 36 (1992) $63-72$.

[5] Bliss J.C., Martin A.J., Identifying NIPF management motivations with qualitative methods, For. Sci. 35 (1989) 601-622.

[6] Bohlin F., Roos A., Wood fuel supply as a function of forest owner preferences and management styles, Biomass Bioenergy 22 (2002) 237-249.

[7] Cabanettes A., Guyon J.P., Relations entre gestion et structure dans les systèmes boisés d'exploitations agricoles, in: Symposium Agriculteurs, agricultures et forêts, Caillez F., Cavailhes J., Hubert B., De Montard F.-X., Guitton J.-L., Terrasson D. (Eds), INRACemagref, Paris, 1994.

[8] Cardon P., Un capital dormant - La transmission patrimoniale de la forêt paysanne en Franche-Comté, Terrain 32 (1999) 113-154.

[9] Davis L. S., Liu G., Integrated forest planning across multiple ownership and decision makers, For. Sci. 34 (1991) 200-226.

[10] Deconchat M., Exploitation forestière et biodiversité : exemple dans les forêts fragmentées des coteaux de Gascogne, Thèse de Doctorat, Université Toulouse III, 1999, $191 \mathrm{p}$.

[11] Deconchat M., Balent G., Cabanettes A., Gibon A., Hewison A.J.M., Bouyjou B., Dedieu G., Gavaland A., Gouaux P., Gonzalez M., Lacombe J.P., Ladet S., Menaut J.C., Monteil C., Ouin A., Salles D., Sarthou J.P., Sourdril A., Un dispositif de recherche pour l'analyse des interactions entre pratiques agricoles et forestières, paysages et processus écologiques, Lyon, France, INRA, in: Symposium final programme PSDR, 2005.

[12] Degron R., Continuités et ruptures dans la gestion des bois communaux au $\mathrm{XIX}^{\mathrm{e}}$ siècle - quelques exemples lorrains, Rev. For. Fr. 51(1999) 425-434.

[13] Dhubain A.N., Wall S. Farmers and rural attitudes to forestry, in: Terrasson F. (Ed.), Public perception and attitudes of forest owners towards forest in Europe, Cost Action E3-WG1 (1994-1998), 1998.

[14] Egan A., Jones S., Do landowner practices reflect beliefs? Implications of an extension-research partnership, J. For. 91(1993) 39-45.

[15] Erickson D.L., Ryan R.L., De Young R., Woodlots in the rural landscape: landowner motivations and management attitudes in a Michigan (USA) case study, Landsc. Urban Plan. 58 (2002) $101-112$.

[16] Evans J., Coppicing and natural disturbance in temperate woodlands - a review, in: Buckley G.P. (Ed.), Ecology and management of coppice woodlands, Chapman and Hall, London, 1992, pp. $79-98$.

[17] Farcy C., Devillez F., New orientations of forest management planning from an historical perspective of the relations between man and nature, For. Pol. Econ. 7 (2005) 85-95.

[18] Fortier A., Le taillis contre la futaie. Différentes manières d'appréhender le paysage forestier ardennais, Étud. Rurales 121-124 (1991) 109-126.

[19] Girard N., Bellon S., Hubert B., Lardon S., Moulin C.H., Osty P.L., Categorising combinations of farmers' land use practices: an approach based on examples of sheep farms in the south of France, Agronomie 21 (2001) 435-459. 
[20] Giudici F., Zingg A., Sprouting ability and mortality of chestnut (Castanea sativa Mill.) after coppicing. A Case study, Ann. For Sci. 62 (2005) 513-523.

[21] Haneca K., Van Hacker J., Beeckman H., Growth trends reveal the forest structure during Roman and Medieval times in Western Europe: a comparison between archaelogical and actual oak ring series (Quercus robur and Quercus petraea), Ann. For. Sci. 62 (2005) 797-805.

[22] IFN, Résultats du $2^{\mathrm{e}}$ inventaire forestier 1988: Département de la Haute Garonne, Toulouse, France: Inventaire Forestier National, 1992.

[23] Karpinen H., Objectives of non-industrial private forest owners: differences and future trends in southern Finland, J. For. Econ. 4 (1998) 147-158.

[24] Kennedy J.J., Thomas J.W., Glueck P., Evolving forestry and rural development beliefs at midpoint and close of the 20th century, For. Pol. Econ. 3 (2001) 81-95.

[25] Kennedy S.H., Spies T.A., Dynamics of hardwood patches in a conifer matrix: 54 years of changes in a forested landscape in Coastal Oregon, USA, Biol. Conserv. 122 (2005) 363-374.

[26] Kurttila M., Uutera J., Sakari M., Kurki S., Pukkala T., Decreasing the fragmentation of old forests in landscapes involving multiple ownership in Finland: economic, social and ecological consequences, For. Ecol. Manage. 166 (2002) 69-84.

[27] Kurtz W.B., Laewis B.J., Decision-making framework for nonindustrial private forest owners: an application in the Missouri Ozarks, J. For. 79 (1981) 285-288

[28] Lanier L., Badré M., Delabraze P., Dubourdieu J., Flammarion J. P., Précis de sylviculture, Nancy, France, ENGREF, 1986, 468 p.

[29] Löfman S., Kouki J., Fifty years of landscape transformation in managed forests of southern Finland, Scand. J. For. Res. 16 (2001) $44-53$

[30] Lönnstedt L., Non-industrial private forest owners' decision process: a qualitative study of goals, time perspective, opportunities and alternatives, Scand. J. For. Res. 12 (1997) 302-310.

[31] Lönnstedt L., Svensson J., Non-industrial private forest owners' risk preferences, Scand. J. For. Res. 15 (2000) 651-660.

[32] Loyland K., Ringstad V., Oy H., Determinants of forest activities a study of private nonindustrial forestry in Norway, J. For. Econ. (1995) 219-236.

[33] Marcin T.C., Integrating social sciences into forest ecosystem management research, J. For. 93 (1995) 29-34
[34] Muraz J., Durrieu S., Labbe S., Andreassian V., Tangara M., Comment valoriser les photos aériennes dans les SIG, Ingénieries, 20 (1999) 39-57.

[35] Nougarède O., La transmission de la forêt paysanne - les bois dans la vie de la famille agricole, in: Actes du colloque Bois et forêts des agriculteurs, Clermont-Ferrand, 20-21 octobre 1999 Cemagref, Paris, 1999, pp. 309-334

[36] Pukkala T., Kangas J., Kniivilä M., Tiainen A.-M., Integrating forest-level and compartment-level indices of species diversity with numerical forest planning, Silva Fenn. 31 (1997) 417-429.

[37] Samples V.A., Building partnerships for ecosystem management on mixed ownership landscapes, J. For. 93 (1994) 41-44.

[38] Soini K., Exploring human dimensions of multifunctional landscapes through mapping and map-making, Landsc. Urban Plan. 57 (2001) 225-239.

[39] Sourdril A., du Bus de Warnaffe G., Pratiques, structures écologiques et représentations sociales autour des forêts paysannes du canton d'Aurignac (Haute-Garonne, France), in: Colloque international La forêt : enjeux comparés des formes d'appropriation, de gestion et d'exploitation dans les politiques environnementales et le contexte d'urbanisation généralisé, Poitiers, France, October 2003.

[40] Sourdril A., du Bus de Warnaffe G., Deconchat M., Garine E., Balent G. Farm foresters in southwestern France: from father to son, differences in representations, ownership strategies and ecological consequences, in: IUFRO symposium Human Dimensions of Family and Farm Forestry, Washington State University, USA, March 29 - April 1 2004, pp. 107-112.

[41] Tarrent R.F., Ewing R.A., Gedney D.R., Forest survey and the nonindustrial private ownership, J. For. 76 (1978) 470-472.

[42] Terrasson D. (Ed.), Public perception and attitudes of forest owners towards forest in Europe - European cooperation in the field of scientific and technical research COST E3-WG1 1994-1998, 1998 , $243 \mathrm{p}$.

[43] Terreaux J.P., Quelques résultats d'économie relatifs à la gestion de la forêt paysanne - définition de trois pistes de recherche, in: Symposium Agriculteurs, agricultures et forêts, Caillez F., Cavailhes J., Hubert B., De Montard F.-X., Guitton J.-L., Terrasson D. (Eds.), INRA-Cemagref, Paris, 1994.

[44] Tran M., La diversité des modes d'utilisation de la forêt dans les exploitations agricoles des coteaux de Gascogne, Mémoire de fin d'études, ENITA-INRA, Clermont-Ferrand, 1995, 97 p. + Appendix. 